\title{
Prevalence of Gingivitis, Plaque accumulation and Decayed, Missing and Filled Teeth among slum population in Bangladesh
}

\author{
Hannan MA ${ }^{1}$, Chowdhury MTH ${ }^{2}$, Khan MAI ${ }^{3}$, Chowdhury AFMA ${ }^{1}$, \\ Shahidullah $\mathrm{KM}^{4}$, Saha $\mathrm{AK}^{5}$, Anjum $\mathrm{A}^{6}$ \\ ${ }^{I}$ Department of Conservative Dentistry and Endodontics, Sapporo Dental College and Hospital, \\ ${ }^{2}$ Department of Dental Public Health, Sapporo Dental College and Hospital, ${ }^{3}$ Department of \\ Paediatric Dentistry, Sapporo Dental College and Hospital, ${ }^{4}$ Department of Prothodontics, Sapporo \\ Dental College and Hospital, ${ }^{5}$ Department of Dental Public Health, City Dental College and Hospital, \\ ${ }^{6}$ Department of Science of Dental Materials, Sapporo Dental College and Hospital. \\ Email: mahannan@sapporodentalcollege.com.bd
}

\begin{abstract}
A cross-sectional survey, using cluster sampling technique, of slum population, was done to explore the oral health status and the prevalence of common oral diseases. A close ended questionnaire comprising Decayed, Missing and Filled Teeth (DMFT) Index, Gingival Index (Löe and Silness) and Plaque Index was applied to evaluate and record oral diseases, in both male and female population, covering a wide range of age groups. Clinical examination was carried out in different slum set ups, including slum schools by trained and calibrated examiners. Three thousand nine hundred and four (3904) slum dwellers participated in the survey. Prevalence of Caries was expressed in mean DMFT, recording of gingival status followed the method of Löe and Silness, oral hygiene status was evaluated using Plaque index. Mean decayed component, of the DMFT, was significantly higher than filling and missing component. Both decayed and missing components showed increasing trend, and filling components decreased as the age progressed. Prevalence of gingivitis and plaque accumulation was remarkably high among slum dwellers. Significantly high level of common oral diseases was found among Tongi slum dwellers.
\end{abstract}

\section{Introduction}

Bangladesh is a very densely populated country in South-Asian region, with a population of over 140 million. ${ }^{1}$ Although the majority $(>75 \%)$ of her people reside in rural areas, internal population density is highest in urban, followed by peri-urban and rural areas. According to UN-HABITAT (2006) report $79 \%$ of these urban populations live in slums in Bangladesh. ${ }^{2}$ The population living in the slums are usually very poor, socio-economically disadvantaged and under privileged. Slum structures ranges from simple shacks to semipermanent structures, lacking basic household utilities. $^{3}$

Tongi is an industrial "suburb", near Dhaka, the capital city of Bangladesh and has one of the largest slum clusters in the country. Most of its inhabitants are migrant population coming from rural areas, who subsists on low wages, under-employed or often unemployed for an indefinite period. The households are overcrowded with poor water and sanitation system. About fifty percent of working slum dwellers usually misses an average of 10 working days in a month because of illness, physical inability due to chronic malnutritution or finding a work fitting to their skill. The health of this underprivileged population is largely neglected because of lack of awareness and low purchasing power. ${ }^{4}$

Oral health is an integral part of general health and well being. Some sporadic studies on oral health, identified high caries prevalence with DMFT ranging from 1.0 to 4.7 among both urban and rural population in Bangladesh., ${ }^{5,6}$ On the other hand, high prevalence of calculus, bleeding on probing and deep periodontal pockets was identified in central and western Bangladesh. Furthermore, the study showed that less than $10 \%$ sample population from all age groups had healthy periodontium. ${ }^{6,7}$ All these studies reveal a clear indication of high prevalence of oral diseases, particularly periodontal diseases in Bangladesh.

Urban planning to accommodate growing slum population requires study to determine demographics and other determinants of improved quality of life, such as health status, health services, financial stability, education and other components of social security. However, scarcity of basic oral health status data among the slum population, several structural and financial constraints is a 
major hindrance for any service delivery or preventive oral health program for these populations. The aim of the present study, therefore, was to explore the prevalence of common oral diseases among the population of Tongi slums, with an objective to find out oral health problems of slums dwellers and trends of distribution of oral diseases, to plan a comprehensive dental preventive program in future.

\section{Materials and Methods}

This Cross-sectional Survey was conducted in twelve slum clusters of Tongi Municipality to find out baseline oral health status. Slum clusters or area are divided according to administrative division formed by Tongi Municipality. The slums clusters in Tongi mainly developed around different industrial facilities. The sampling method used in this survey was the cluster random sampling technique, which included participants of all age groups and both sexes. The survey had the sample size of three thousand nine hundred and four (3904) subjects.

A simple close-ended questionnaire was used to collect information on demographics and oral health status such as caries, missing and filled teeth, gingivitis and plaque status. Standardized oral disease indicators like DMFT, Löe and Silness Gingival Index and Plaque Index were used in the questionnaire to record the data along with basic demographic information. DMFT is a standard universally accepted caries index. Here ' $D$ ', 'M' and ' $F$ ' refers to decayed, missing and filled teeth respectively. All 28 teeth except third molar were examined and scoring was done accordingly. Individual and total score of different component of DMFT index were calculated. "Löe and Silnes Gingival index" is based on the type of gingival appearance, presence or absence of gum bleeding and level of gingival inflammation. Six index teeth were examined and scored with a range from 0 to 3 . Plaque index is based on level of accumulation of soft debris calculated over four surfaces of six index teeth. Score ranging from 0 to 3 , was based on level of accumulation of plaque. ${ }^{14}$ The questionnaires were filled up by trained survey personnel following oral examination.

Survey proposal was submitted to the Tongi municipality authority to get permission before initiation of the work. Verbal consent was taken from the subjects prior to examination and data collection and the purpose of the survey was explained to them beforehand. In addition, subjects were assured about the ethical aspects and confidentiality of the collected data.

Survey personnel, who were qualified dentists, were trained both theoretically and practically about the importance of accuracy of data collection and the procedure to be followed, before going to the operation area. The training included examination procedures, criteria for the various oral diseases and clinical conditions likely to be observed and recorded during survey. Examiners were calibrated to minimize intra examiner and inter examiner variability.

Data were collected during dental camps, where services were offered to the attending participants free of cost. At first twelve slum clusters were selected randomly. Subsequently, subjects were chosen from each cluster regardless of any particular age group and sex. Following consent from the subject, detailed oral examination was carried out to measure DMFT score, gingivitis and plaque status. Periodontal probe, caries explorer, tweezers, cotton rolls and pellets, headlamps, gloves, masks and antiseptic solution were used during the survey. All instruments were cleaned with soap and water before disinfecting in antiseptic solution. All subjects were positioned upright and examined by using headlight/torch light and other relevant dental instruments. However, subjects requiring emergency dental care were referred to Sapporo Dental college Hospital, located at the vicinity of the project area.

Data gathered from the Survey were entered into the SPSS - version 12.0. Data analysis includes cross tabulation of DMFT, gingivitis and dental plaque in relation to sex and different age groups. Chi-square test, one way analysis of variance (ANOVA) and $95 \%$ confidence interval were used to show the statistical significance.

\section{Results}

Three thousand nine hundred and four (3904) samples were surveyed. Analysis of the sample revealed predominantly female participants $(59 \%)$, in comparison to male $(40.5 \%)$. Young and early adult age group (ranging from 11 to 40 years) covered the mainstream of the samples, which was about seventy-two percent of the total sample size. On the other hand, older population (over 60 years) was the minority group.

Mean DMFT according to the gender and age were illustrated in Table I and II. Mean DMFT, in both sex combined, was 3.01, which was higher among male (3.11) in comparison to female (2.94). Mean decayed component of the DMFT was considerably higher than filling and missing component, while missing component was more than filled part.

Mean DMFT increased with the progression of age. However mean DMFT was lowest (1.51) in the 010 year's age group and highest (10.61) in the older age group (over 60 years). This difference in mean DMFT according to age was highly significant 
statistically. Both decayed and missing components revealed increasing trend with age, was also statistically significant. On the other hand, filling components decreased as the age progressed.

Gingival status is shown according to gender and age in table III. This table demonstrates high prevalence of severe gingivitis in the older age group (above 30 years). On the other hand, prevalence of moderate gingivitis was high in younger age groups (0-30 years). However, in combined age groups, prevalence of normal gingiva was very low (ranged from 0 to 4.1 percent). Prevalence of both moderate and severe gingivitis was higher among female than male and prevalence of various categories of gingivitis in relation to both sex and age groups were statistically significant.

Plaque accumulation around the teeth is shown in table IV, according to age and sex. High percentage of moderate and abundant plaque accumulation was observed and the accumulation was more in female than male. Abundant plaque accumulation was observed more among adult and older age groups, while moderate plaque accumulation was recorded high among younger age groups (0- 30 years), and this difference was statistically significant.

However, in all age groups percentage of no plaque status was very low (ranged from 0 to 3.2 percent).

Table I: Mean DMFT according to gender

\begin{tabular}{cccc}
\hline \multirow{2}{*}{ DMFT } & Sex & $\begin{array}{c}\text { Mean (95\% } \\
\text { Confidence Interval } \\
\text { for Mean) }\end{array}$ & $\begin{array}{c}\text { Standard } \\
\text { Deviation }\end{array}$ \\
\hline \multirow{3}{*}{ Decayed teeth } & Male & $2.11(1.97-2.25)$ & 2.90 \\
& Female & $2.07(1.96-2.19)$ & 2.81 \\
& Total & $2.10(2.01-2.19)$ & 2.84 \\
Missing Teeth & Male & $0.98(0.85-1.12)$ & 2.71 \\
& Female & $0.85(0.74-0.97)$ & 2.85 \\
& Total & $0.91(0.82-0.99)$ & 2.79 \\
Filled Teeth & Male & $0.01(0.00-0.02)$ & 0.17 \\
& Female & $0.02(0.01-0.03)$ & 0.29 \\
Decayed, Missing & Total & $0.02(0.01-0.02)$ & 0.25 \\
\& Filled Teeth & Male & $3.11(2.90-3.31)$ & 4.21 \\
& Female & $2.94(2.77-3.11)$ & 4.17 \\
& Total & $3.01(2.88-3.14)$ & 4.18 \\
\hline
\end{tabular}

Table II: Mean DMFT according to age

\begin{tabular}{|c|c|c|c|c|c|c|c|c|}
\hline \multirow{2}{*}{$\begin{array}{l}\text { Distribution } \\
\text { of age }\end{array}$} & \multicolumn{2}{|c|}{ Decayed teeth* } & \multicolumn{2}{|c|}{ Missing Teeth* } & \multicolumn{2}{|c|}{ Filled Teeth } & \multicolumn{2}{|c|}{$\begin{array}{c}\text { Decayed, Missing \& Filled } \\
\text { Teeth* }\end{array}$} \\
\hline & $\begin{array}{c}\text { Mean }(95 \% \\
\text { Confidence } \\
\text { Interval for Mean) }\end{array}$ & $\begin{array}{c}\text { Std. } \\
\text { Deviation }\end{array}$ & $\begin{array}{c}\text { Mean }(95 \% \\
\text { Confidence Interval } \\
\text { for Mean) }\end{array}$ & $\begin{array}{c}\text { Std. } \\
\text { Deviation }\end{array}$ & $\begin{array}{c}\text { Mean (95\% } \\
\text { Confidence } \\
\text { Interval for Mean) }\end{array}$ & $\begin{array}{c}\text { Std. } \\
\text { Deviation }\end{array}$ & $\begin{array}{c}\text { Mean }(95 \% \\
\text { Confidence } \\
\text { Interval for Mean) }\end{array}$ & $\begin{array}{c}\text { Std. } \\
\text { Deviation }\end{array}$ \\
\hline $0-10$ years & $\begin{array}{c}1.42 \\
(1.24-1.59)\end{array}$ & 1.70 & $\begin{array}{c}0.09 \\
(0.01-0.18)\end{array}$ & 0.94 & $\begin{array}{c}0.01 \\
(0.01-0.02)\end{array}$ & 0.10 & $\begin{array}{c}1.51 \\
(1.30-1.72)\end{array}$ & 2.02 \\
\hline $11-20$ years & $\begin{array}{c}1.44 \\
(1.34-1.55)\end{array}$ & 1.70 & $\begin{array}{c}0.11 \\
(0.08-0.14)\end{array}$ & 0.47 & $\begin{array}{c}0.01 \\
(0.00-0.01)\end{array}$ & 0.13 & $\begin{array}{c}1.56 \\
(1.45-1.67)\end{array}$ & 1.80 \\
\hline 21-30 years & $\begin{array}{c}1.90 \\
(1.77-2.03)\end{array}$ & 2.13 & $\begin{array}{c}0.39 \\
(0.32-0.46)\end{array}$ & 1.11 & $\begin{array}{c}0.01 \\
(0.00-0.02)\end{array}$ & 0.16 & $\begin{array}{c}2.31 \\
(2.15-2.46)\end{array}$ & 2.47 \\
\hline $31-40$ years & $\begin{array}{c}2.38 \\
(2.18-2.57)\end{array}$ & 2.80 & $\begin{array}{c}1.0 \\
(0.85-1.15)\end{array}$ & 2.14 & $\begin{array}{c}0.03 \\
(0.01-0.05)\end{array}$ & 0.30 & $\begin{array}{c}3.41 \\
(3.16-3.67)\end{array}$ & 3.67 \\
\hline $41-50$ years & $\begin{array}{c}3.06 \\
(2.66-3.46)\end{array}$ & 4.18 & $\begin{array}{c}1.91 \\
(1.54-2.29)\end{array}$ & 3.94 & $\begin{array}{c}0.02 \\
(0.00-0.04)\end{array}$ & 0.22 & $\begin{array}{c}5.0 \\
(4.45-5.54)\end{array}$ & 5.68 \\
\hline 51-60 years & $\begin{array}{c}3.58 \\
(2.79-4.37)\end{array}$ & 5.37 & $\begin{array}{c}3.45 \\
(2.64-4.26)\end{array}$ & 5.52 & $\begin{array}{c}0.06 \\
(0.05-0.17)\end{array}$ & 0.74 & $\begin{array}{c}7.08 \\
(5.96-8.21)\end{array}$ & 7.63 \\
\hline Over 60 years & $\begin{array}{c}3.63 \\
(2.70-4.55) \\
\end{array}$ & 4.87 & $\begin{array}{c}6.98 \\
(5.53-8.43)\end{array}$ & 7.62 & $\begin{array}{c}0.00 \\
(0.00-0.00)\end{array}$ & 0.00 & $\begin{array}{c}10.61 \\
(8.97-12.25) \\
\end{array}$ & 8.65 \\
\hline
\end{tabular}

Table III: Gingival status according to gender and age

\begin{tabular}{|c|c|c|c|c|c|}
\hline \multirow{2}{*}{\multicolumn{2}{|c|}{$\begin{array}{c}\text { Gender and } \\
\text { age } \\
\text { distribution }\end{array}$}} & \multicolumn{4}{|c|}{ Gingivitis } \\
\hline & & $\begin{array}{l}\text { Normal } \\
\text { Gingiva }\end{array}$ & $\begin{array}{c}\text { Mild } \\
\text { Gingivitis }\end{array}$ & $\begin{array}{l}\text { Moderate } \\
\text { Gingivitis }\end{array}$ & $\begin{array}{c}\text { Severe } \\
\text { Gingivitis }\end{array}$ \\
\hline \multirow{2}{*}{ Sex* } & Male & $29(1.8 \%)$ & $279(17.6 \%)$ & $756(47.8 \%)$ & $518(32.7 \%)$ \\
\hline & Female & $24(1.0 \%)$ & $344(14.8 \%)$ & $1180(50.8 \%)$ & $774(33.3 \%)$ \\
\hline \multirow{7}{*}{ 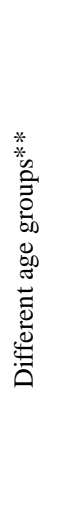 } & $\begin{array}{l}0-10 \\
\text { years }\end{array}$ & $15(4.1 \%)$ & $128(34.6 \%)$ & $193(52.2 \%)$ & $34(9.2 \%)$ \\
\hline & $\begin{array}{l}11-20 \\
\text { years }\end{array}$ & $23(2.3 \%)$ & $263(26.2 \%)$ & $579(57.8 \%)$ & $137(13.7 \%)$ \\
\hline & $\begin{array}{l}21-30 \\
\text { years }\end{array}$ & $6(.6 \%)$ & $130(12.8 \%)$ & $550(54.0 \%)$ & $333(32.7 \%)$ \\
\hline & $\begin{array}{l}31-40 \\
\text { years }\end{array}$ & $7(.9 \%)$ & $70(8.7 \%)$ & $344(42.8 \%)$ & $382(47.6 \%)$ \\
\hline & $\begin{array}{l}41-50 \\
\text { years }\end{array}$ & $1(.2 \%)$ & $19(4.5 \%)$ & $176(41.8 \%)$ & $225(53.4 \%)$ \\
\hline & $\begin{array}{l}51-60 \\
\text { years }\end{array}$ & $0(.0 \%)$ & $7(3.9 \%)$ & $54(30.0 \%)$ & $119(66.1 \%)$ \\
\hline & $\begin{array}{c}\text { Over } 60 \\
\text { years }\end{array}$ & $1(.9 \%)$ & $6(5.5 \%)$ & $40(36.7 \%)$ & $62(56.9 \%)$ \\
\hline & Total & $53(1.4 \%)$ & $623(16.0 \%)$ & $1936(49.6 \%)$ & $1292(33.1 \%)$ \\
\hline
\end{tabular}

Table IV: Plaque accumulation according to gender and age

\begin{tabular}{|c|c|c|c|c|c|}
\hline \multirow{2}{*}{\multicolumn{2}{|c|}{$\begin{array}{l}\text { Gender and } \\
\text { age } \\
\text { distribution }\end{array}$}} & \multicolumn{4}{|c|}{ Dental Plaque } \\
\hline & & No Plaque & $\begin{array}{l}\text { A Film of } \\
\text { Plaque }\end{array}$ & $\begin{array}{c}\text { Moderate } \\
\text { Accumula } \\
\text { tion }\end{array}$ & Abundant \\
\hline \multirow{3}{*}{ Sex } & Male & $22(1.4 \%)$ & $249(15.7 \%)$ & $776(49.1 \%)$ & $535(33.8 \%)$ \\
\hline & Female & $23(1 \%)$ & $313(13.5 \%)$ & $1164(50.1 \%)$ & $822(35.4 \%)$ \\
\hline & $\begin{array}{l}0-10 \\
\text { years }\end{array}$ & $12(3.2 \%)$ & $119(32.2 \%)$ & $198(53.5 \%)$ & $41(11.1 \%)$ \\
\hline \multirow{6}{*}{ 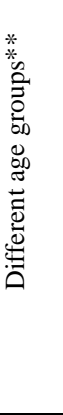 } & $\begin{array}{l}11-20 \\
\text { years }\end{array}$ & $22(2.2 \%)$ & $248(24.8 \%)$ & $575(57.4 \%)$ & $157(15.7 \%)$ \\
\hline & $\begin{array}{l}21-30 \\
\text { years }\end{array}$ & $4(0.4 \%)$ & $113(11.1 \%)$ & $561(55.1 \%)$ & $341(33.5 \%)$ \\
\hline & $\begin{array}{l}31-40 \\
\text { years }\end{array}$ & $5(0.6 \%)$ & $54(6.7 \%)$ & $351(43.7 \%)$ & $393(48.9 \%)$ \\
\hline & $\begin{array}{l}41-50 \\
\text { years }\end{array}$ & $1(0.2 \%)$ & $19(4.5 \%)$ & $163(38.7 \%)$ & $238(56.5 \%)$ \\
\hline & $\begin{array}{l}51-60 \\
\text { years }\end{array}$ & $0(.0 \%)$ & $6(3.3 \%)$ & $54(30.0 \%)$ & $120(66.7 \%)$ \\
\hline & $\begin{array}{l}\text { Over } \\
60 \\
\text { years }\end{array}$ & $1(0.9 \%)$ & $3(2.8 \%)$ & $38(34.9 \%)$ & $67(61.5 \%)$ \\
\hline & otal & $45(1.2 \%)$ & $562(14.4 \%)$ & $1940(49.7 \%)$ & $1357(34.8 \%)$ \\
\hline
\end{tabular}




\section{Discussion}

From the findings of the study, it was evident that populations living in the slum area were deprived of any basic interventional or preventive program related to oral diseases and no survey was ever done to evaluate their oral health status. However, this survey was the first of this kind, done to assess the oral health condition and disease prevalence among the slum dwellers of Tongi.

Overall, mean DMFT was significantly high in both male and female and this was almost concomitant with the national average (mean DMFT 1.1 to 4.7). ${ }^{6}$ Both decayed and missing components increased and filling components decreased with the progression of age. Moreover, components like filling and missing teeth which are related to timely dental treatment, were lower than decayed component. This gives a clear indication that people in the slum areas have almost no access to oral treatment or no preventive program was in place to arrest the progression of oral diseases.

The results of gingivitis and periodontal condition were similar with studies done previously, in Bangladesh, ${ }^{6,7}$ which confirms the validity of findings of this study. Results of the survey reveal overall poor periodontal and oral hygiene status of slum dwellers. Majority of the participants had abundant and moderate plaque accumulation which is a clear sign of poor oral hygiene status of the study population. Higher prevalence of gingivitis was observed in both younger and older age groups because of poor oral hygiene. This supports the findings that slum dwellers living in socioeconomically deprived condition have high level of dental diseases and poor oral health status. ${ }^{8-12}$

Untreated periodontitis and dental caries leads to eventual loss of teeth. Early loss of teeth causes impaired function of mastication leading to impaired digestion and malabsorption of nutrients and affects the general health of the individual. ${ }^{13}$ However, majority of the Tongi slum dwellers have been suffering from chronic malnutrition, ${ }^{4}$ and severe dental diseases might have contributed further to aggravate the condition.

The poor slum dwellers are in a continuous state of struggle for subsistence, day in day out. Therefore, if they come across serious health problems, including oral health, their life is further jeopardized. Furthermore, high prevalence of dental diseases and its associated pain significantly hamper the quality of life and hinder their daily activities. Eventually, this result in significant loss of working hours of this poor community, who often are under-employed and struggle to have square meals.
A comprehensive interventional and preventive program is therefore suggested for these underprivileged slum dwellers. This will include timely intervention, implementation of oral health promotion, motivation and creation of awareness among the slum dwellers, along with continuous follow up and monitoring system.

In conclusion, high level of dental diseases was identified among Tongi slum dwellers, which confirms the previously reported data, in socially deprived areas in other parts of the world. The results of the survey can be used as a model in planning oral health programs, scaled up for other urban and peri-urban slum areas in Bangladesh and beyond.

\section{Acknowledgment}

This research project was supported by the Embassy of Japan, Bangladesh, under its Grassroots Human Security Projects. We would like to express our deepest gratitude to all the involved members of the Embassy relating to the project, and in particular, former Ambassador of Japan, His Excellency, Mr Matsushiro Horiguchi, for his kind gesture and personal initiative to materialize this project, devoted for humanitarian cause. We would also like to extend our gratitude to the officials and members of Tongi Municipality, for taking necessary steps and helping for smooth implementation of the project in slum clusters.

\section{References}

1. Bangladesh Bureau of Statistics, Statistical Pocket Book of Bangladesh, Government of Bangladesh, 2006.

2. Cameron S. Education in slums of Dhaka, Bangladesh, conference paper, $10^{\text {th }}$ UKFIET International Conference on Education and Development, 2009, URL: http://www.create-rpc.org/pdf_documents/ UKFIET stuartcameronpaper. pdf, date of access: $8^{\text {th }}$ October, 2012.

3. UN-HABITAT. the Challenge of Slums: Global Report on Human Settlements 2003, press release on its report, 2007.

4. International Food Policy Research Institute, Bangladesh- Jessore and Tongi-Urban Livelihoods in the Slums, Washington DC, USA, 2000.

5. Ullah MS, Aleksejuniene J, Eriksen HM. Oral Health of 12-year-old Bangladeshi children, Acta Odontologica Scandinavica 2002;60: 117-22.

6. Arvidson-Bufano UB, Holm AK. Dental health in urban and rural areas of central and western Bangladesh, Odontostomatol Trop 1990;13(3): 81-86.

7. Van Palenstein Helderman WH, Joarder MAK, Begum A. Prevalence and severity of periodontal diseases and 
dental caries in Bangladesh, International Dental Journal 1996; 46: 76-81.

8. Prendergast MJ, Beal JF, Williams SA. The relationship between deprivation, ethnicity and dental health in 5-year-old children in Leeds, UK. Community Dent Health 1997; 14(1): 18-21.

9. Maupome G. An introspective qualitative report on dietary patterns and elevated levels of dental decay in a deprived urban population in Northern Mexico. ASDC J Dent Child 1998; 65(6): 437-40.

10. Sweeney PC, Nugent Z, Pitts NB. Deprivation and dental caries status of 5-year old children in Scotland. Community Dent Oral Epidemiol 1999; 27(2): 152-9.
11. Locker D. Deprivation and oral health: a review. Community Dent Oral Epidemiol 2000; 28(3): 161-9.

12. Squassi A, Mauro S, Mauro MJ et al. Relationship between oral health in children and poverty related factors. Acta Odontol Latinoam 2008; 21(1): 49-56.

13. Hannan MA, Shahidullah KM, Khan MAI et al. Role of Nutrition in Common Dental Diseases in Rural Bangladesh, Bangladesh Med. Res. Counc. Bulletin 2006; 32(2): 55-9.

14. Hiremath SS. Textbook of Preventive and Community Dentistry, ${ }^{\text {st }}$ ed, India: Elsevier; 2007. 